\title{
Social investigations as a measuring instrument of construction industry in the areas of Polish districts with prefabricated buildings
}

\author{
Anna Ewa Ostańska \\ Department of Architecture and Urban Planning, Lublin University of Technology, \\ e-mail:a.ostanska@pollub.pl
}

\begin{abstract}
We analyze Town area with prefabricated buildings of poor energetic quality. We survey opinions on possible energetic improvements according to inhabitants' age. Inhabitants are interested in improvements and willing to pay. Inhabitants want information on possible pro-energetic solutions. Surveys like this encourage people to think of benefits of energetic improvements.
\end{abstract}

Keywords: energetic quality; social inquiries; living quality; prefabricated buildings, sustainable energy systems.

\section{Admission}

In the chosen model of town three housing estates were selected and then 21 prefabricated buildings were pointed out for the sake of the research. Later on the opinions of the inhabitants were investigated by means of social inquiry which made it possible to obtain information concerning the energetic assessment of buildings by the inhabitants. Information was obtained from 4 social age groups. Thus, the effects of the research which was carried out are dependent upon the energetic question consciousness of the inhabitants and their interest in sustainable energy systems. If they are more conscious, they express their wish of co-deciding and participating in proenergetic works, which has an indirect influence upon the energetic policy of Poland.

\section{Introduction}

The article contains exemplary analyses of the effects of proenergetic activities worldwide and social investigations in Europe as well as the results of the author's social investigations carried out in several Polish housing estates in the area of south-eastern Poland.The object of the research analyses is the proenergetic potential of districts with prefabricated buildings investigated by means of inquiries carried out as direct interviews. Thus the results obtained may be helpful in working out the guiding principles for the model of proenergetic activities aimed at energy saving in multi-family buildings on a housing estate scale. It is worth mentioning that the inhabitants declared a potential financial participation in the suggested activities improving the living conditions in the prefabricated dwelling houses. 


\section{The necessity of proenergetic activities}

An important fact to be taken into account is the following :the research which was carried out abroad $[1 ; 2 ; 3 ; 4 ; 5 ; 6 ; 7 ; 8]$ proved that it is not enough to introduce legal regulations to make people save energy or provide funds to carry out the investments like energy saving windows or the alternative systems of obtaining energy. It is worth mentioning that the subsidy must be preceded by social education in its broad sense - in this respect social inquiries may be useful. If was proved by a series of investigations in Sweden which showed that in spite of obtaining the funds $79 \%$ of inhabitants bought the energy saving windows of worse parameters of heat permeability $\left(1.2 \mathrm{~W} / \mathrm{m}^{2} \mathrm{~K}\right)$, than was possible $\left(1.1 \mathrm{~W} / \mathrm{m}^{2} \mathrm{~K}\right)$ with the means they had at their disposal [1]. The lack of social consciousness is a reason why fund reduction results in limiting of the range of activities [6], that is why Vinea took up an attempt of complex statement of necessary works [9] and the necessity to continue them in the housing cooperatives as well [10]. However, the range of activities should not be limited but only accomplished by stages in which the inhabitants' will to take up the activities should be taken into account. Stopping or even slowing down the thermomodernization process does not reduce the maintenance charges. The investigation on a housing estate scale in south-eastern Poland has proved that from 1996 to 2010 there was a substantial increase of thermal energy fees 1 GJ exceeding the level of $150 \%$ while with the successively accomplished process of thermomodernization in a housing estate it has increased only by $40 \%$ during the 14 years since 1996 [17]. Interruption of the thermomodernization process results in keeping the energy consumption in a building at the constant level, and the growing cost of thermal energy will result in the fact that the final user will suffer most [11]. Beck and Park's investigations carried out in Sweden, Great Britain, Denmark, Belgium, Germany, France, Holland, Finland, Austria, Portugal, Spain and Ireland have proved the decrease of government funds since 1970 to 2007 and that is why the European Union funds would be necessary [12] but at the time of crisis it is rather difficult. However, while planning the proenergetic strategy we should take into account the potentialities of the inhabitants and their declared willingness to participate financially in the activities to be accomplished. It is also possible in other countries, not only in Poland, but only after carrying out social investigations on a large scale and with the successive accomplishment of the determined activities, i.e. according to the means they possess, so that the inhabitants could notice and appreciate the effects ${ }^{1}$ and only then can the assumed range of activities be carried into effect and the energy saving equipment can be introduced.

That is why it has been stated that only strategic planning taken up in cooperation with the inhabitants can result in lower energy consumption, lower cost of flat maintenance and also the improvement of living conditions in the prefabricated buildings. Instruments for the analysis of electrical energy consumption in a dwelling house at the planning stage have already been elaborated in other countries [13]. A method of reducing energy consumption by means of a MACES instrument was presented.

MACES takes into account the multiaspectual system of activities, controlling intelligent systems, installations in a building and behavior of the inhabitants [14]. It allows better planning of the energy consumption and eliminates situations in which the real consumption is even by $50 \%$ bigger than it was planned [15]. Exploitation of the natural resources and the resulting regular increase of energy carrier prices and the commitment to the EU justify seeking the methods of energy saving in dwelling houses.

\footnotetext{
1 You can even start from minor renovation works like painting the staircase in order to break the barrier of social distrust, which can be confirmed by the author's research from 2004 [16].
} 
That is why the author's long-term investigations published, among others, in monographs [16], [17] and Przegląd Budowlany (Construction Review) [18, 19, 20,21] confirm the fact that social education is extremely important. It can be accomplished, e.g. through the cyclic social research [22]. Thus every renovation or proenergetic activity should be taken up after a social consultation, otherwise every initiative is doomed to fail, as can be seen in the examples from eastern Germany [23]. Cooperation with inhabitants gave numerous positive effects, which were obtained e.g. in Sweden, Denmark, Western Germany or Austria [24]. The dialogue with inhabitants was taken up not only at the stage of planning and designation but also at the stage of accomplishment.

It should be taken into account that the structure of dwelling resources in Poland is complex and varied with respect to the payments made by the inhabitants of buildings of various forms of ownership. On the basis of GUS (Central Statistical Office) 2011 it was stated that the differences (fig. 1), in dwelling houses can even amount to $26 \%$ as far as the central heating (c.h.) and hot water (h.w.), 20\% - the cost of cold water and sewage disposal and to $11 \%$ - the cost of rubbish disposal.

In order to carry out the social research, the buildings that were chosen from the analyzed forms of ownership were the ones governed by the housing cooperative in which the cost of heating energy is biggest and reaches $66 \%$. Obviously it results from the amount of those resources in our country and the time of their origin which was presented on fig. 1.

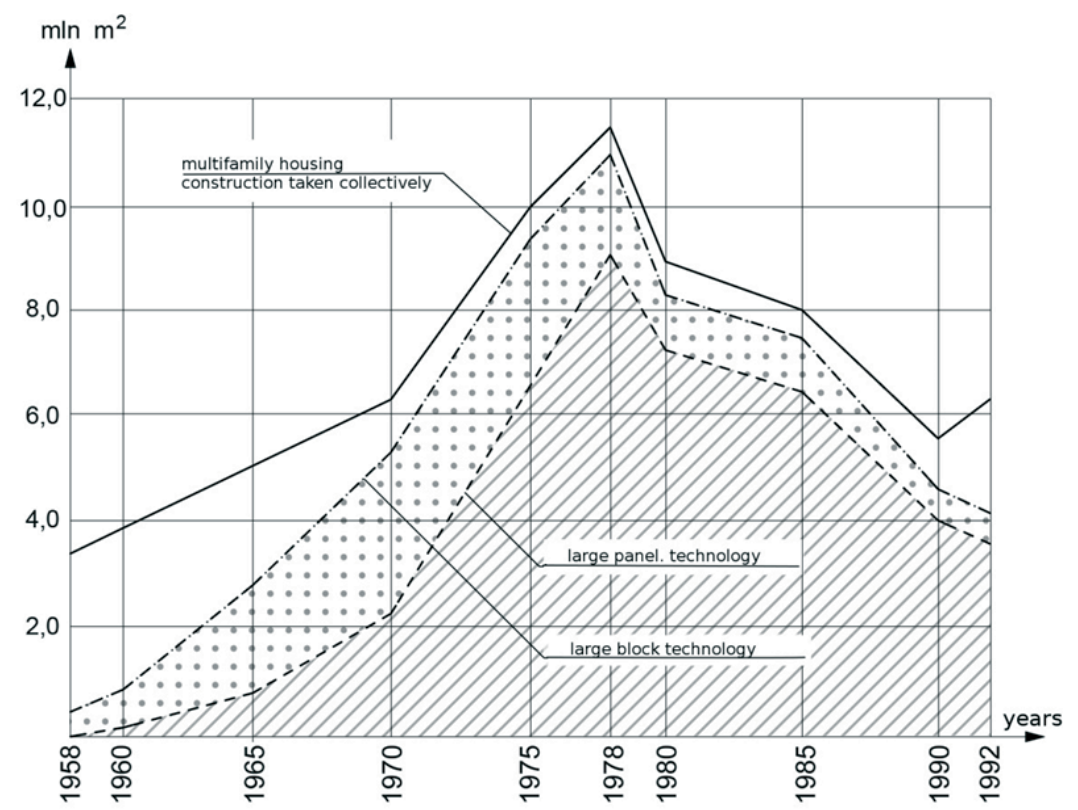

Fig. 1. The share of industrialized technologies using prefabricated proportioned elements in the multifamily housing construction from 1858 to 1992 taken from the GUS basis [26]

As far as the current situation in Poland is concerned about $2 / 3$ of the society live in multifamily prefabricated buildings. They were already constructed in Poland in the 50s of the 20'th c. Their mass production surpassing other technologies occurred in $60 \mathrm{~s}$ and $70 \mathrm{~s}$ of 20 'th century. A meaningful decrease of housing production was noted from 1978-1980 and then, in the consecutive years production of prefabricated buildings, especially the large panel ones has progressively disappeared. Taking into consideration the mass produc- 
tion of buildings in a cooperative form of construction and the lack of investor's supervision no one paid close attention to the energetic quality of the prefabricated houses. Differences of the average energy consumption $\mathrm{kWh} / \mathrm{m}^{2}$ amounted to $50 \%$ at the maximum consumption level and $35 \%$ at the minimum one (fig. 2).

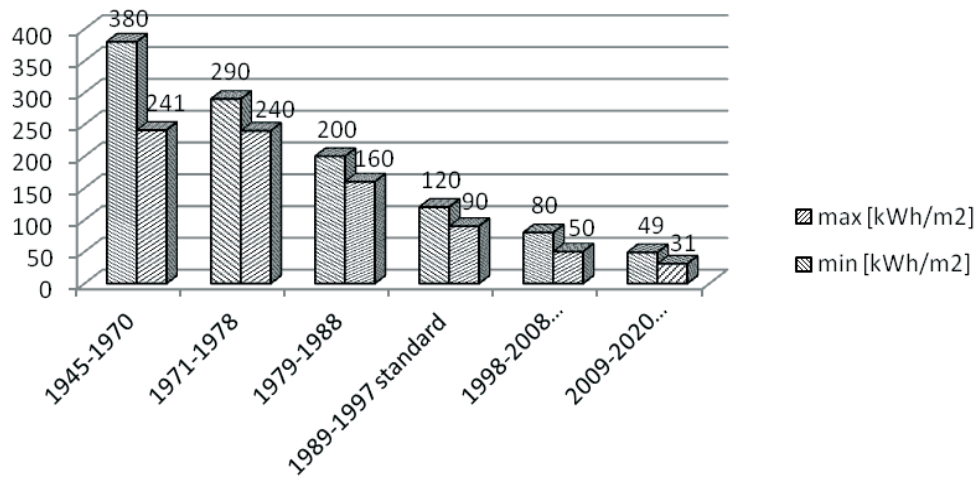

Fig. 2. An average annual energy consumption in $\mathrm{kWh} / \mathrm{m}^{2}$ of usable floor area in dwelling houses built in Poland in various periods of time and in the currently constructed energy saving buildings [27]

On the basis of the research analysis of prefabricated buildings, accomplished in the cooperative system of construction and, presently, management, they are estimated as having the biggest potential for proenergetic systemic activities in view of the great frequency of their appearance in Poland [28]. Social research seems to be the proper measure of the social potential of the areas of Polish housing estates with prefabricated buildings, which has been presented in the current article in a detailed way.

According to the opinion of T. Biliński [29], even today there is a need for such a type of design and giving all users equal chances of access to the natural resources, so that we could leave as much as possible for the future generations. Stability of balanced development is based on the rational management of cultural and natural resources, non-renewable or with a limited capability of renewal and renovation, both on the local and the global scale.Certainly the first thing we should do is to aim at completing the thermomodernization processes of dwelling houses which are quite advanced in Poland now and at general education of the society, and then at employing the optimum systems of energy saving installations rather than the newest or most expensive ones. Such an order of activities, aimed at the renewable energy sources will first of all allow to minimize the costs in order to establish a strategy of proenergetic activities based on the common opinion of managers and inhabitants.

\subsection{The need for social activities}

Undoubtedly in Poland we should take up complex and long-term activities aiming at improving the state of countryside, buildings and nature. Other crucial questions are: the improvement of living conditions of the inhabitants and creating development opportunities for the whole districts, housing estates, towns and regions. Otherwise they will encounter problems resulting from wearing away both in the technical and moral sense and the aspect of the energetic value of buildings which will generate a growing burden of costs for the users [11]. The source of the problems, among others, is in the growing maintenance cost of the currently used flats, the growing cost of energy and the heat losses resulting from the wear of the objects. 
It is worth stressing that in other European countries valorization of prefabricated buildings was carried out by means of renovation or modernization, the range of the suggested activities was being intensely consulted with inhabitants, there were talks with the tenants and some of them were chosen as contact people. This was the basis for planning the order of activities in the investment process, special programs were worked out to support the venture both in the technical and financial respect. The plan was accomplished in close cooperation and agreement with the inhabitants of the districts. Special renovation teams originated gathering managers of partnerships and cooperatives but also technical consultants, architects and people with an immense understanding of social matters [30], which really facilitated the contact with all the interested parties. In Finland, the influence of the users upon the consumption of energy was researched (11\%) and it was found to be insignificant [7]. But the research of N. Djuric and V. Novakovich provided evidence that the electric energy consumption depends on the level of its use in a given building i.e. the number of users and frequency of switching off ventilators [8]. The analysis of Dutch investigations has confirmed that the very ventilation of rooms has a crucial influence upon the energy consumption in a building $[2,3,4,5]$. O.S. Guerra made an inquiry concerning the question of energy consumption - by mail - and she obtained an insufficient sample for further analyses [31]. It was a mistake not only to elaborate a comprehensive inquiry consisting of a large number of questions (as was stated by the author of the inquiry herself) but also to use mail to accomplish the task.

However, in Poland hitherto carried out social research (apart from the author's investigations hereto quoted) concentrates upon the problems of isolated social groups. An example can be found in the social research carried out in 2001 among the young people from Bemowo in Warsaw which concerned the degree of identification of the young people with their environment. In spite of the lack of cultural or sport infrastructure the young people made attempts to find some facilities to spend their free time but they were treated badly by the police [32]. In the investigations described the middle-aged and elderly people were completely neglected. The practical experience gained during the work upon the article (2004-2012) proves that the housing cooperatives in Poland avoid more extensive social investigations, especially the ones concerning technical or energetic problems of buildings and their surroundings and infrastructure. The managers of cooperatives and the quarters in their management express the opinion that the questions from social inquiries arouse expectations of the inhabitants that are impossible to satisfy.

\subsection{The choice of a research area}

The object chosen for the research is a town from Lublin voivodship situated in southeastern Poland. A representative of the region is a typical town, Lubartów, $20 \mathrm{~km}$ away from Lublin (fig. 3) with a little more than 20.000 inhabitants [33].

Most of them live in prefabricated buildings. In order to check the knowledge and the way of reasoning of the inhabitants of Lubartów concerning the problems of their living environment and the possible directions of proenergetic works - in their opinion - social research was carried out concerning the area of the Building Cooperative of Lubartów in 2010. According to the data based on authority [34] the area of activity of the Building Cooperative equals $288,364 \mathrm{~m}^{2}$. There are 94 buildings there and they comprise 3,267 flats inhabited by 3,201 members of the Cooperative; there are also 41 various facilities and 99 garages. During the last three years the Building Cooperative has renovated the dwelling resources, mainly by insulating buildings making use of thermomodernization credits. Two modern multifamily buildings were commissioned for exploitation. 


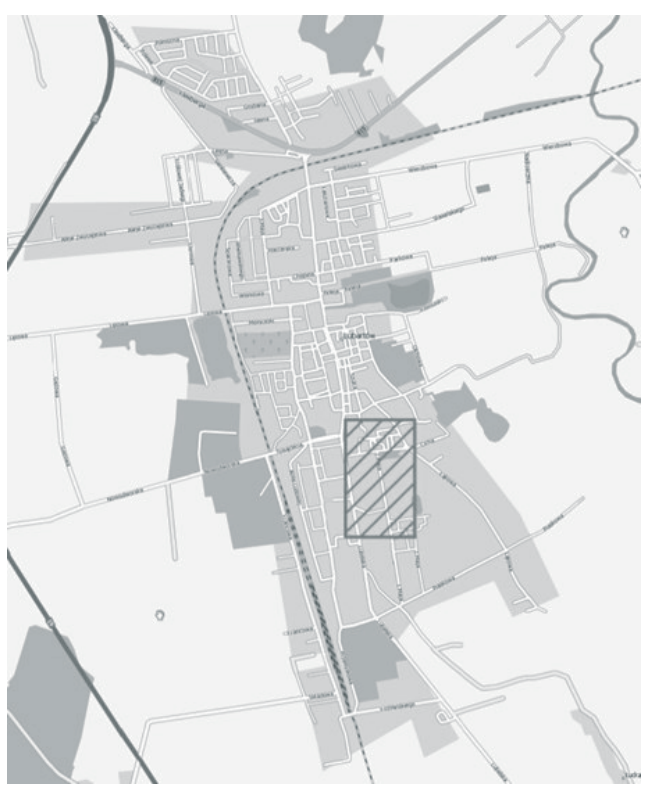

Fig. 3. Lubartów $2010-$ a map of the town, The research area is delimited

The area of the Building Cooperative of Lubartów was regarded as representative because of the number of prefabricated multifamily buildings typical of every Polish town or city that are to be found there. Three of the nine Building Cooperative estates in Lubartów were chosen for investigation. Inquiries were made in 21 multi-family buildings (fig. 4) constructed in the technology of prefabricates.

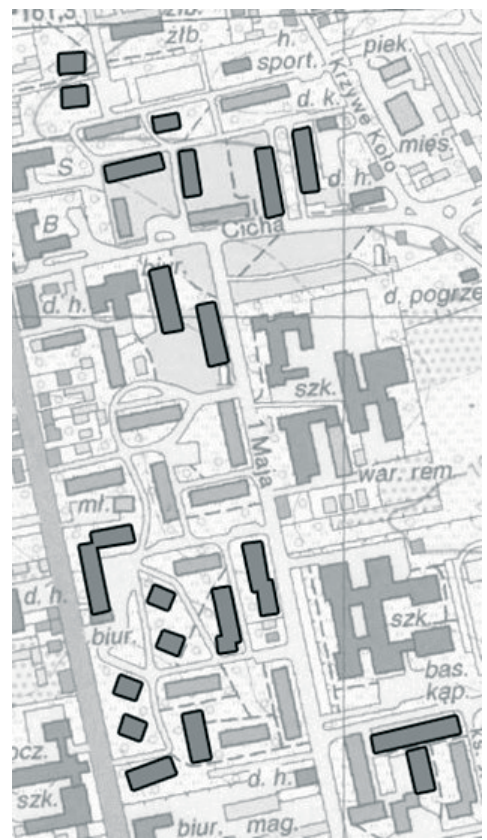

Fig. 4. Lubartów 2010. Representative buildings in the chosen research area 


\subsection{The objective and method of making the inquiry}

The objective of the research was to arise the interest of the inhabitants in the opportunities of influencing the decisions concerning energy saving, which could help to improve the energetic quality of prefabricated dwelling houses as well as stating the direction of improvement activities which are further referred to as proenergetic ones.

The research was based on the patterns of sociological inquiries [35], enriched with methods and techniques resulting from social experiences described by Sztumski [36].Environment inquiries were made among the inhabitants of the quarters chosen for investigation. They were carried out as direct interviews, which was a unique action accomplished in Poland on such a scale only by the author. In every flat only one person was interviewed. All the rules of inquiry researches were observed. A group of over $14 \%$ of the population of the town has been examined.

The prepared template of the inquiry comprised 27 questions: 10 of them ...closedended, 15 half-open-ended and 2 open-ended ones. Closed-ended questions in the logical and technical sense consisted in choosing one of several possible answers and regarded information concerning: sex, age, level of education, migration or participation in the cost of the suggested proenergetic activities. Half-open-ended questions (i.e. closed-ended in the technical sense and open in its logical aspect comprised a choice of logically open answers (it was possible to choose each of them or none) out of many variants of logically closedended technical solutions and included reconditioning and proenergetic activities which are possible to be accomplished as well as the actualization of the degree of utilization of the resources of the quarter. Open-ended questions - both in the logical and technical sense consisted in answering one question in an unconstrained way and they referred mainly to individually accomplished works in the flats and the expectations of the inhabitants in case of participation.

The suggested choice of questions is helpful, among others in: estimation of the participation of particular age groups divided into sex and education level subgroups and the recognition of the range of possible proenergetic activities in a building and in the surrounding area that would be determined by means of direct social consultations. One hundred and three inquiries were completed which is a representative sample (almost $6 \%$ of 1,752 flats in 21 buildings) for further analyses.

\subsection{Social studies and discussions}

Section 6 contains the results and analysis of social surveys conducted in southeastern Poland Research

\subsection{The social structure of the quarters}

It is worth stressing here that the analysis which was carried out was based upon the age criterion of the inhabitants (fig. 5).

Thus, it was a hint concerning the type of group to be dealt with in case of taking up any discussions with regard to the improvement of the quality of life. The statistic analysis proves that the largest group consists of the inhabitants aged $46 \div 65(43 \%)$ and the immediately following one is older than $66(26 \%)$ while a little less numerous group is aged $26 \div 45$ $(25 \%)$. Moreover, one more fact to take into consideration is that in the group of inhabitants taking part in the investigation, the share of women is $72 \%$ while the share of men is only $28 \%$ (fig. 6). 


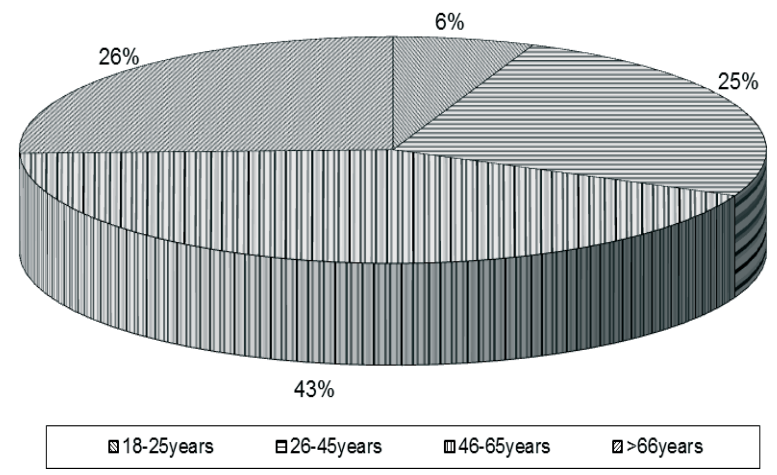

Fig. 5. The age of the inhabitants, according to the age criterion in the Building Society in Lubartów, November 2010

The share of women in the overall number $-72 \%$ $4 \%$

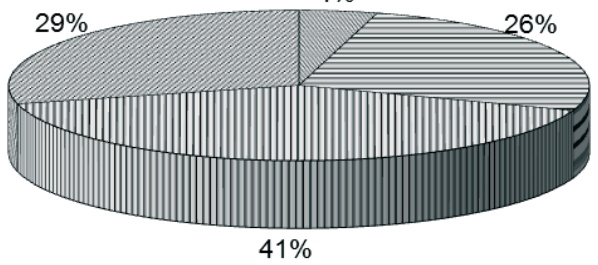

\$18-25years $\boxminus 26-45 y e a r s ~ \square 46-65 y e a r s ~ \square>66 y e a r s$
The share of men in the overall number $-28 \%$

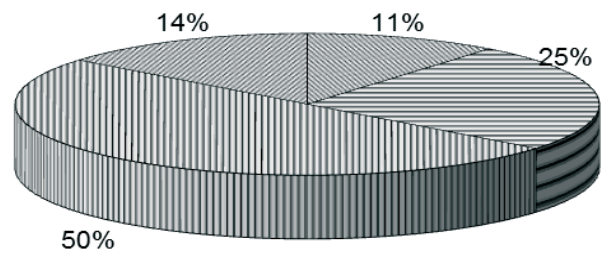

ه18-25years $\boxminus$ ㄴ-45years $\mathbf{0}$ 46-65years $\square>66$ years

Fig. 6. The sex of the inhabitants taking part in the inquiry according to the age criterion of the Building Society in Lubartów, November 2010

\subsection{The social opinion concerning the way of using energy in dwelling houses}

The article presents the opinion of the inhabitants concerning the indispensable proenergetic activities to improve the quality of living in the housing environment. That is why one more aspect that was investigated was the declared will of financial participation in the initiative they had chosen. The results were gathered in charts according to the age criterion, so that the people who prepare plans of specific activities aimed at energy saving on the scale of a building and a quarter could gain some knowledge as to the group of inhabitants to be dealt with.

On the basis of buildings constructed in the technology of prefabricates the following aspects were analyzed: the use of common space and the quality of the electrical household equipment in the flats, the reasons of migration and the chances of improvement of the energy saving policy. In view of the fact that a part of the possible energy saving activities in a building depends upon the opinion of the inhabitants and upon their way of behavior, a crucial thing is to help them realize the problem, which was confirmed by the analysis of foreign investigations described earlier.

Thus, on the basis of the research (fig. 7) it was stated that the inhabitants of investigated buildings do not use the laundry $(0 \%)$.

The reason is that most of them use their own washing machines in their flats (94\%): they wash and dry their clothes in their flats and only occasionally they make use of the access to the drying room $(6 \%)$. That is why, in spite of the advanced technology of spin- 
ning in automatic washing machines, the level of humidity in flats is higher than it was primarily assumed. Hence, it is necessary to take up the activities aimed at removing the excessive humidity out of the dwelling space by improving flat ventilation.

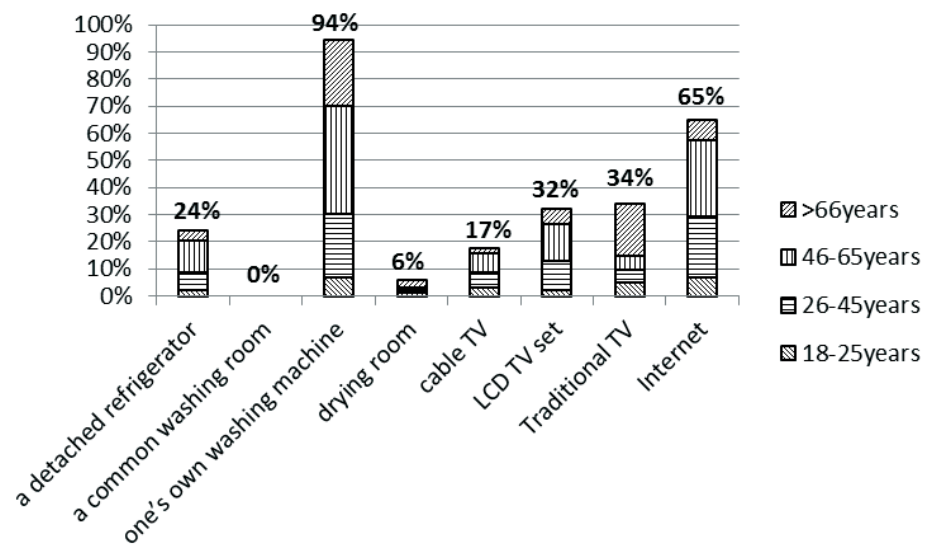

Fig. 7. Making use of the common facilities and electrical household equipment in flats according to the age criterion of the Building Society in Lubartów, November 2010

Moreover, the research has confirmed that the inhabitants use the electrical household equipment of a varied level of energy consumption. That means that people who use energy consuming refrigerators pay higher bills for energy than others. The tenants of the Building Cooperative of Lubartów often watch cable TV, some of them even up to 8 hours a day. They also make use of the LCD TV sets (32\%) or energy consuming analogue ones $(34 \%)$. That is why the inhabitants need some kind of educational activities, in order to make them realize their faulty habits and the excessive energy consumption, especially with reference to the 46-65 age group, as they are the ones who most often use the energy consuming electrical household equipment .

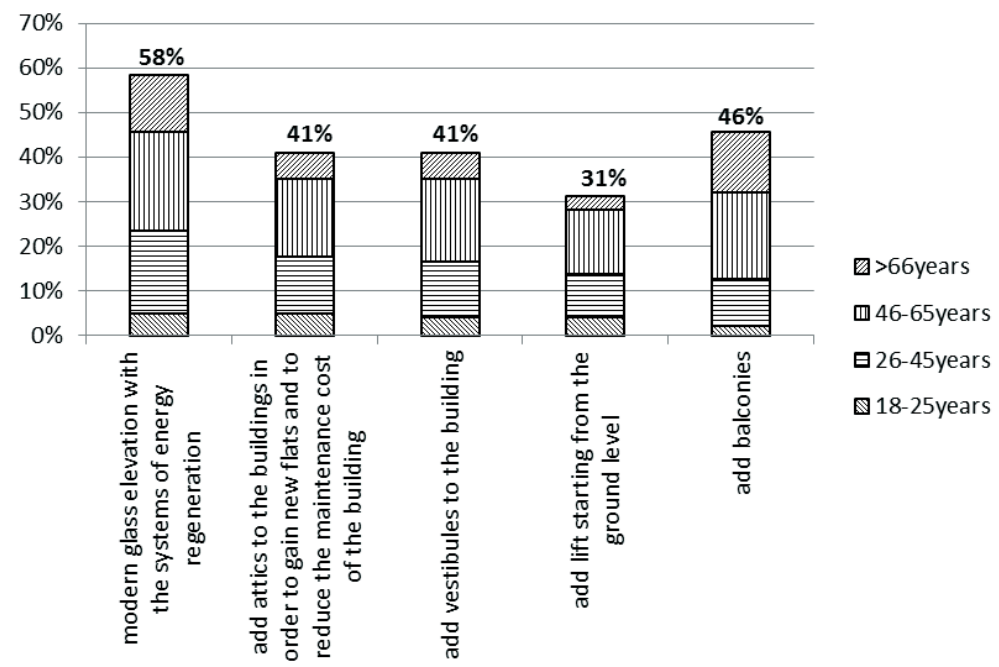

Fig. 8. Improvement of the energetic quality of a low building, according to the age criterion of the Building Society in Lubartów, November 2010 
However, the inhabitants notice the chances of improvement of the energetic quality of low multifamily buildings (fig. 8) in the modern elevation lining with the system of energy recuperation (58\%) and adding or exchanging balconies (46\%) which would allow to remove the thermic bridges as well as reducing the heat emission and regeneration of solar energy. Moreover, equally important and gaining great interest of the inhabitants $(41 \%)$ are such questions as adding vestibules and attics in order to gain some more living space which could reduce heat emission through the flat roof as a result. The new living space would make maintenance cost lower on the scale of a single flat. A certain group of inhabitants (32\%) expressed their wish of the functional improvement of the building by the reconstruction of lifts so that they could start from the ground level. And although the requirement seems impossible to accomplish on the basis of the ordinary budget of the cooperative, in case of adding the attics it becomes more probable, because the cost of lift construction would be taken up by the new inhabitants as they are granted an agreement to use the existing infrastructure by the rest of the inhabitants (terminals, installations, dustbins, green areas, recreation areas, pavements, car-parks, etc.).

The inhabitants are convinced that several things are important for reducing the cost of the consumed electric energy in flats (fig. 9), like installing motion sensors in staircases (76\%), exchange of the electric installation and introduction of the LED lighting in flats (50\% each). They pay a lot of attention to the air quality, that is why they have chosen $(49 \%)$ the exchange of gravity ventilation for mechanical one with recuperation. Almost $50 \%$ of the inhabitants are interested in introducing the LED lighting in the staircases (47\%) but in the author's opinion, as well as in the opinion of a lot of managers, it can prove to be more expensive than in flats because of frequent robberies.

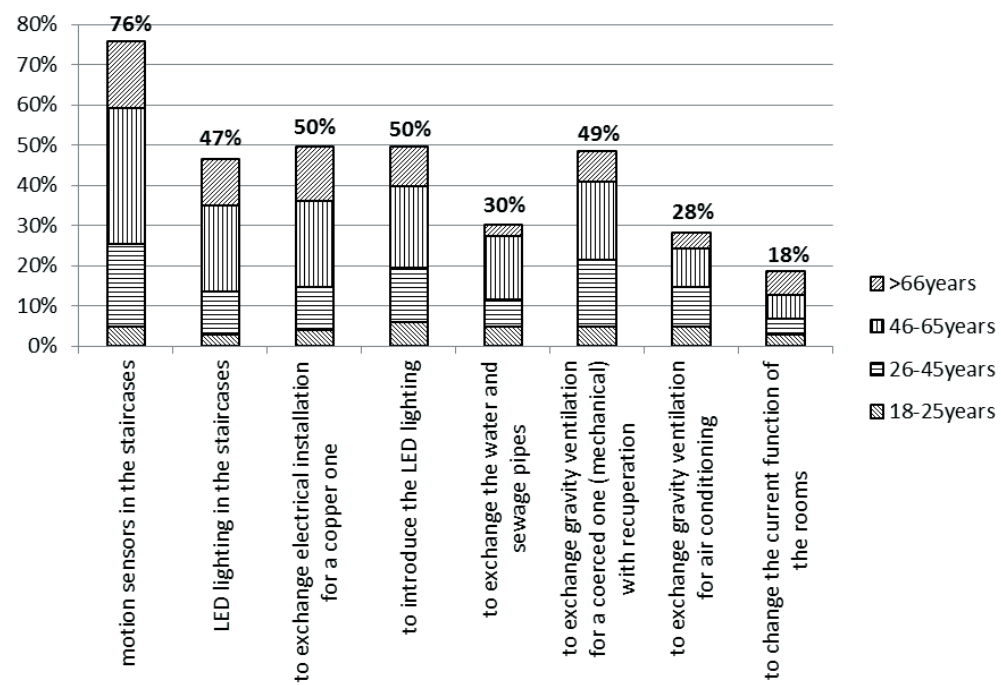

Fig 9. Reducing the cost of the consumed electric energy in flats in the opinion of inhabitants, according to the age criterion of the Bulding Society in Lubartów, November 2010

The effect of the research concerning prefabricated dwelling houses was indicating priority proenergetic works which could, in the opinion of the inhabitants, bring most substantial savings of energy in a building (fig. 10) and in which they would like to participate. Thus, the analysis of the research has proved that the inhabitants indicated the use of renewable energy sources as the changes to be accomplished, i.e.; setting up solar $(65 \%)$ 
and photovoltaic (64\%) installations. Apart from modern energy saving solutions the inhabitants are interested in the exchange of electric installation (51\%), improvement, renovation and lining of the balconies (39\%) and a slightly smaller number of people is interested in insulating the basement ceiling (38\%). They also express their support for the idea of adding a personal lift (35\%) and introducing monitoring of energy consumption in flats $(33 \%)$. Moreover, the research analysis has proved that for the inhabitants of low prefabricated buildings the most important thing is to change the electric installation in flats (51\%). The next task is improvement and lining of the balconies (39\%). A little less people are interested in adding a lift which could start from the ground level (35\%), insulating the basement ceiling (34\%) and lighting exchange in the staircases (32\%). The social research carried out by means of inquiries confirmed arousing the wish of participation in the inhabitants. That means that apart from their monthly payments on behalf of the Cooperative energy providers, the inhabitants $(25 \%)$ declare their share in bearing the expense of those proenergetic works they have chosen themselves (fig. 10) in the form of additional yearly payment of 500 PLN.

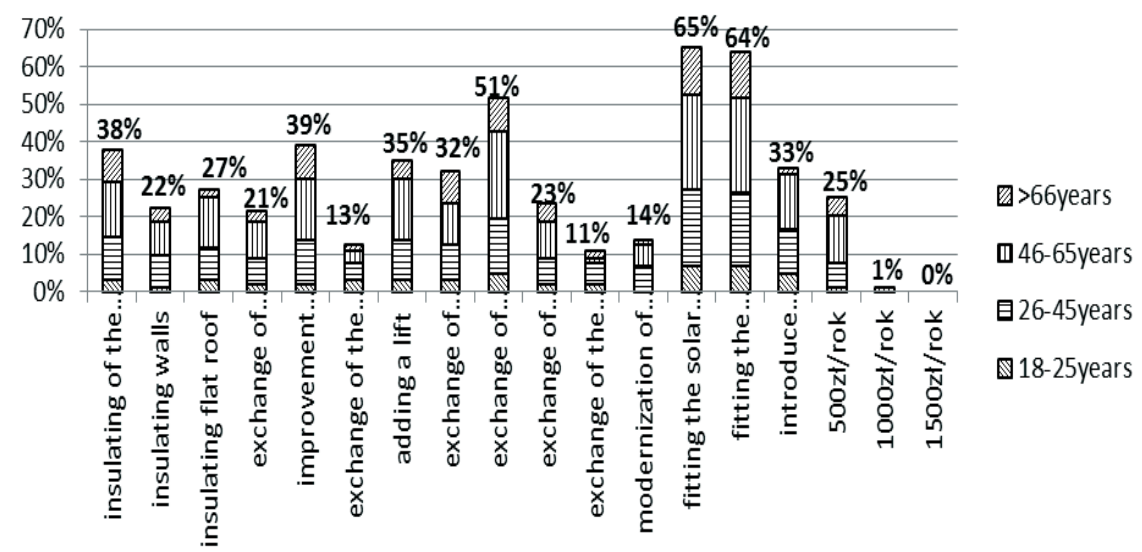

Fig. 10. The opinion of the inhabitants concerning the order of the urgent proenergetic works including the declaration of the wish of participation in costs, according to the age criterion of the Building Society in Lubartów, November 2010

\section{Conclusions}

In order to sum up the research it should be stated that the dialogue with the inhabitants of multifamily buildings which was taken up in this way, confirmed their interest in taking part in the activities aimed at the reduction of energy consumption as well as codeciding and co-financing of the proenergetic enterprises. In the analyzed quarters of Lubartów the inhabitants were informed by means of inquiries carried out as direct interviews about the possible ways of accomplishing proenergetic works in their flats, in the buildings and its surroundings. Participation declared by the inhabitants is especially important while preparing the plans of proenergetic activities in prefabricated buildings. The building rule in Poland related to promoting thermomodernization and renovation is inadequate for most prefabricated buildings, because it designates only the rules of covering a part of the cost rather than the whole sum of thermomodernization and renovation enterprises making use of the finds of Thermomodernization and Renovation [37].

On the basis of investigation analysis of the Building Cooperative of Lubartów the range and order of activities were defined in cooperation with the inhabitants and with 
regard to their declared participation. Although the inhabitants show great interest in renewable energy sources, they also notice the uncompleted thermomodernizations. The range and order of works chosen by the inhabitants constitute the proenergetic potential coefficient which should be taken into account in the areas with prefabricated buildings. Recognition of the needs of specific quarters and people who inhabit them by means of social inquiries may be a contribution to elaborating the proenergetic guiding principles that should be used while spanning the realization process at given area.

Certainly, the suggested method of social research concerning the state and range of works aimed at energy saving on the scale of a flat, building and its surroundings is possible to accomplish in the whole territory of Europe. At the time of crisis it is the cheapest means of education and obtaining information from the inhabitants as well as encouraging them to take up common activities and to participate.

In the author's opinion in order to solve the problems of energy management in Poland we should treat globally energy production and consumption in our country, especially in housing management which is made possible by elaborating the model of proenergetic activities aimed at energy saving and will be presented in separate publications.

\section{Acknowledgement}

This work was financially supported by Ministry of Science and Higher Education within the statutory research number S/19/2012.

\section{References}

1. Nair G., Mahapatra K., Gustavsson L. Implementation of energy-efficient windows in Swedish single-family houses. Appiled Energy 89 (2012) 329-338.

2. Guerra-Santin O., Itard L., Visscher H., The effect of occupancy and building characteristics on energy use for space and water heating in Dutch residential stock. Energy and Buildings 41 (2009) 1223-1232.

3. Herkel S., Knapp U., Pfafferott J. Towards a model of user behaviour regarding the manual control of windows in office buildings. Building and Environment 43 (2008) 588-600.

4. Rijal H.B., Tuohy P., Humphreys M.A., Nicol J.F. Using results from field surveys topredict the effect of open windows on thermal comfort and energy use in buildings. Energy and Buildings 39 (2007) 823-836.

5. Schweiker M., Shukuya M., Comparison of theoretical and statistical models of airconditioning-usage behavior in a residential setting under Japanese climatic conditions. Building and Environment 44 (2009) 2137-2149.

6. Martinaitis V., Kazakevičiusb E., Vitkauskasb A. A two-factor method for appraising building renovation and energy efficiency improvement projects. Energy Policy 35 (2007) 192-201.

7. Kyrö R., Heinonen J., Säynäjoki A., Junnila S. Occupants have little influence on the overall energy consumption in district heated apartment buildings. Energy and Buildings 43 (2011) 3484-3490.

8. Djurica N., Novakovicb V. Identifying important variables of energy use in low energy office building by using multivariate analysis. Energy and Buildings 45 (2012) 91-98.

9. Vinea EL., Kazakevicius E. Residential energy use in Lithuania: the prospects for energy efficiency. Energy 24 (1999) 591-603.

10. Kazakevicius E., Schipper L., Meyers S. The residential space heating problem in Lithuania. Energy Policy 26(11) (1998) 831-858.

11. Mlecnik E., Schützec T., Jansena S.J.T., de Vriesc G., Visschera H.J., van Halc A. End-user experiences in nearly zero-energy houses. Energy and Buildings 49 (2012) 471-478.

12. Baek C.H., Park S.H. Changes in renovation policies in the era of sustainability. Energy and Buildings 47 (2012) 485-496. 
13. Yu P.C.H., Chow W.K. A discussion on potentials of saving energy use for commercial buildings in Hong Kong. Energy 32 (2007) 83-94.

14. Klein L., Kwak J-Y., Kavulya G., Jazizadeh F., Burcin Becerik-Gerber B., Varakantham P., Tambe M. Coordinating occupant behavior for building energy and comfort management using multi-agent systems. Automation in Construction 22 (2012) 525-536.

15. Fabi V., Andersen R.V., Corgnati S., Olesen B.W. Occupants' window opening behaviour: A literature review of factors influencing occupant behaviour and models. Building and Environment 58 (2012) 188-198.

16. Ostańska A. Podstawy metodologii tworzenia programów rewitalizacji dużych osiedli mieszkaniowych wzniesionych $w$ technologii uprzemystowionej na przykładzie osiedla im. St. Moniuszki w Lublinie, Politechnika Lubelska, Monografie Wydziału Inżynierii Budowlanej i Sanitarnej Vol. 1, Wydawnictwa Uczelniane Lublin 2009, p. 1-173 (Methodological rudiments of creating programs of revitalization of big housing quarters built in industrialized technology, on the example of St. Moniuszko's quarter in Lublin).

17. Taczanowska T., Ostańska A. Dokładność realizacji a potrzeba modernizacji budynków wielkoplytowych. Wydawnictwo Medium 2012, p. 1-184 (Accuracy of accomplishment vs. the necessity of modernization of large panel buildings).

18. Ostańska A. Badania społeczne przyczynkiem do opracowania programu rewitalizacji osiedli z budynkami prefabrykowanymi. A monograph of an interdisciplinary character. Oficyna Wydawnicza Uniwersytetu Zielonogórskiego, Zielona Góra 2009, p. 435-446. (Social research as a contribution for elaborating the revitalization program of the quarters with prefabricated buildings).

19. Ostańska A. Możliwości i potrzeby poprawy warunków zamieszkania w opiniach mieszkańców lubelskiego osiedla. Przegląd Budowlany nr 4/2011, miesięcznik PZiTB, p. 182-185. (The possibilities and necessity to improve the dwelling conditions in the opinions of inhabitants of one of Lublin's quarters).

20. Ostańska A. Ocena możliwości poprawy jakości życia w budynkach prefabrykowanych w opinii ich mieszkańców. Oficyna Wydawnicza Politechniki Białostockiej 2011. ISSN 2081-3279, p. 361-368. (The assessment of the possibility of the quality of living improvement in prefabricated buildings in the opinion of their inhabitants).

21. Taracha K., Ostańska A., Nowak S. Propozycja poprawy jakości życia w budynkach prefabrykowanych. Przegląd Budowlany nr 09/2012, Miesięcznik PZiTB, Wa-wa 2012, p. 36-41. (The suggestion of improvement of living quality in the prefabricated buildings).

22. Ostańska A. Zmiany w preferencjach mieszkańców osiedla z budynkami prefabrykowanymi po pięciu latach od chwili pierwszej ankiety spotecznej. Przegląd Budowlany 12/2010. Miesięcznik PZiTB, p. 46-51. (Preference changes of the inhabitants of a quarter with prefabricated buildings five years after the first social inquiry).

23. Czarnigowska A., Ostańska A. Programy rewitalizacji osiedli z zabudowa prefabrykowana na przykladzie Frankfurtu nad Odra. Przegląd Budowlany 11/2011, miesięcznik PZiTB, p. 63-67. (Revitalization programs of the quarters with prefabricated buildings on the example of Frankfurt on Odra).

24. Kapller V. z zespołem. Plattenbausiedlungen. Ernrurung des baukulturellen Erbes in Wien und Bratislava. Fraunhofer IRB Verlag 2009, p. 7-220.

25. Data base of the Main Statistical Office, 2011.

26. Nowak Z. Struktura budownictwa mieszkaniowego w miastach, zrealizowanego w technologiach uprzemysłowionych. Centralny Ośrodek Badawczo-Projektowy Budownictwa Ogólnego. Budownictwo i Gospodarka Miejska nr 3/95, p. 11-13. (The structure of the housing constructions in towns accomplished in industrial technologies).

27. Data base of the Ministry of Infrastructure, 2008.

28. Ostańska A. Metoda projektowania działań, służacych podwyższaniu efektywności energetycznej budynków mieszkalnych. Lublin 2013, monograph, typescript. (The method of planning activities aimed at increasing the energetic effectiveness of dwelling houses). 
29. Bliński T. Terminologia $w$ działalności inwestycyjno-budowlanej, Izba Projektowania Budowlanego. Izba Projektowania Budowlanego, W-wa 2007, p. 206. (Terminology in constructioninvestement activities).

30. Dąbrowski B. Zróbmy domy ze skrzyń. the source: Internet 2003. (Let's build houses of boxes).

31. Guerra-Santin O. Behavioural patterns and user profiles related to energy consumption for heating. Energy and Buildings 43 (2011), p. 2662-2672.

32. Sołoducha K. Jak uczłowieczamy wielka płytę? cz.2., the source - Internet - actualization 12.08.2003. (How can we make large panel human? - part 2).

33. Data base of the Central Statistical Office of 31st December 2010.

34. Data base of the Building Society, Lubartów, the state of 2010.

35. Gruszczyński LA. Kwestionariusze $w$ socjologii. Budowa narzędzi do badań surveyowych. Wydawnictwo Uniwersytetu Śląskiego, Katowice 2001, p. 33-34. (Inquries in Sociology. Creating tools for survey investigation).

36. Sztumski J. Wstęp do metod i technik badań społecznych. Uniwersytet Śląski Zeszyt 136. Katowice 1976 i późniejsze (do 2001), p. 38-39 i 98-99. (Introducion to methods and techniques of social research).

37. The Law of 21 st November 2008 of supporting thermomodernization and renovation, art. 1.

\title{
Badania społeczne, jako instrument zwiększający efektywność energetyczną budownictwa w obszarach osiedli polskich z budynkami prefabrykowanymi
}

\author{
Anna Ewa Ostańska \\ Katedra Architektury, Urbanistyki i Planowania Przestrzennego, Politechnika Lubelska, \\ e-mail:a.ostanska@pollub.pl
}

Streszczenie: Analizujemy obszary miejskie z prefabrykowanymi budynkami o niskiej jakości energetycznej. Za pomocą ankiety badamy opinie na temat możliwych ulepszeń energetycznych i analizujemy według wieku mieszkańców. Mieszkańcy są zainteresowani zmianami i chętni by brać udział w finansowaniu. Mieszkańcy potrzebują informacji na temat możliwych rozwiązań proekologicznych. Tego rodzaju ankiety zachęcają ludzi do myślenia o korzyściach z ulepszeń energetycznych.

Słowa kluczowe: jakość energetyczna, ankiety społeczne, jakość życia, prefabrykowane budynki, systemy energii odnawialnej. 